\title{
Energy efficiency governance in the EU-28: analysis of institutional, human, financial, and political dimensions
}

\author{
Guillermo Ivan Pereira • Patrícia Pereira da Silva
}

Received: 15 July 2016/Accepted: 3 April 2017

C) Springer Science+Business Media Dordrecht 2017

\begin{abstract}
The European Union in line with its climate and energy strategy has presented a renewed ambition for the post-2020 period, towards 2030, through the Clean Energy for All Europeans policy package proposals. A new binding target of minimum 30\% for energy efficiency improvements is in the horizon, as well as the identified need for a stronger governance framework to support its delivery. This research contributes to a better understanding of energy efficiency governance by analysing a set of indicators covering aspects related to institutional, human, financial, and political dimensions. The results obtained provide a more
\end{abstract}

Electronic supplementary material The online version of this article (doi:10.1007/s12053-017-9520-9) contains supplementary material, which is available to authorized users.

G. I. Pereira $(\bowtie) \cdot$ P. P. da Silva

Energy for Sustainability Initiative, Faculty of Sciences and Technology, Mechanical Engineering Department, University of Coimbra, Rua Luís Reis dos Santos, 3030-788 Coimbra, Portugal e-mail: gpereira@student.dem.uc.pt

G. I. Pereira • P. P. da Silva

INESC Coimbra, Institute for Systems Engineering and Computers at Coimbra, Rua Sílvio Lima, Pólo II,

3030-290 Coimbra, Portugal

G. I. Pereira

MIT Portugal Program in Sustainable Energy Systems, 77

Massachusetts Avenue, Cambridge, MA 02139, USA

P. P. da Silva

CeBER, Center for Business and Economics Research, Faculty of Economics, University of Coimbra, Av. Dias da Silva,

165-3004-512 Coimbra, Portugal detailed perspective on the European Union level and Member State governance capacities. These indicate the need to develop institutional capacities related to the transposition of legislation and directives. In parallel, the disparities between individual Member State governance capacities should be considered when devising and implementing future policies. The implications for policymakers include the need for a more robust governance monitoring and reporting system, including the development of transparent and comparable indicators, as well as a more comprehensive assessment of the impact of good governance on delivering energy efficiency improvements.

Keywords Energy efficiency · European Union · Governance $\cdot$ Energy policy $\cdot$ Indicators $\cdot$ Capacities

\section{Introduction}

Creating stimuli towards a more energy-efficient European Union (EU) has been a key pillar in the energy policy agenda (Schlomann et al. 2015). Member States have been called to collaborate further on this effort through the Energy Efficiency Directive (EED) (European Union 2012b) to ensure the achievement of the proposed energy efficiency (EE) targets by 2020 of $20 \%$ reduction of primary energy consumption (European Commission 2011a, b). Implementing actions that contribute to greater $\mathrm{EE}$ in the $\mathrm{EU}$ is crucial. Developing programmes that engage different stakeholders is an essential part to deliver such goals. 
Additionally, to defining a goal and driving Member States to implement a set of actions, it is also relevant to ensure that complementary support structures exist, which can be expressed by the resources being dedicated to EE progress. Moreover, the resources allocated through these support structures can also facilitate the process of delivering a secure, sustainable, and competitive energy system for Europe's citizens (European Commission 2011a, b).

Whilst the EU strives to follow the set plan for energy and climate for 2020, the European Commission (EC) has already defined the pipeline beyond 2020 and towards 2030. In this new policy framework, the EE ambitions are greater, with an initially proposed target of minimum $27 \%$ improvement target towards 2030, presented in 2014 (European Commission 2014d; European Council 2014), which evolved into a $30 \%$ binding minimum improvement target, presented in 2016, as part of the proposals resulting from the Clean Energy for All Europeans policy package (European Commission 2016a, b). This new level of ambition is based on the premise of the successful achievement of the 20\% EE target for 2020 and on stronger and more coordinated actions towards 2030 (European Commission 2015a, 2017a).

In parallel with the more ambitious EE target, the new climate and energy policy agenda towards 2030 encompasses reaching a minimum share of $27 \%$ of renewable energy on the energy mix, in comparison to the set target of $20 \%$ for 2020 as well as a reduction of at least $40 \%$ on greenhouse gases (GHGs), compared to the 20\% target for 2020 (European Commission 2014c). This evolution is backed by a set of governance guidelines to ensure the effective implementation of action plans and Member State collaboration to achieve the set targets, which has gained further impetus with the implementation of the EU's Energy Union policy package, established in 2015 (European Commission 2015a, c). Noteworthily, the assessments concerning the implementation status of the Energy Union presented in 2015 (European Commission 2015d) and in 2017 (European Commission 2017b) continue to highlight the importance of a robust governance framework and adequate monitoring.

This increased focus on the governance aspects of climate and energy policies also represents the need to further develop the existing governance capacities at the Member State level for delivering the planned ambitions.

It is important to highlight that of the proposed energy and climate targets for 2020 , only the one related to
EE has been at risk of not being met. In 2014, the EC estimated that with the current efforts, the EU would only reach $17 \%$ of energy efficiency improvement, falling short on $3 \%$ from its $20 \%$ target (European Commission 2014a; Harmsen et al. 2014). Despite this possible underachievement, a positive evolution is visible from the estimation presented in 2009, which indicated that at the efforts from that time, only a $9 \%$ energy efficiency increase would be reached, falling short on 11\% (European Commission 2011a). These figures present a positive evolution towards the policy targets; however, a small gap on EE represents a risk that must be understood, managed, and mitigated.

The aim of this paper is to present and discuss a number of different quantitative and qualitative indicators on governance capacities and analyse them through the EE governance analysis framework proposed by Jollands and Ellis (2009). Through this research, we are able to present an EU-level perspective, as well as provide information for each Member State existing governance capacities.

Our approach enables an analysis on the existing governance capacities, which represent the current level of support from areas necessary to the successful delivery of the planned EE improvements. Governance capacities are expressed through a set of indicators that facilitate the measurement of aspects linked to governance of EE. Within this research, governance capacities serve as a proxy for the analysis of the existing support structures across the EU for the delivery of the EE planned targets (Turner et al. 2015).

This research is designed to provide insights on current strengths and weaknesses of EE governance capacities in the EU. These are important from a policymakers' perspective when designing, developing, or evaluating policy agendas and possible targets for future implementation. These indications gain further relevance for the EU case in specific as the new climate and energy agenda towards 2030 presents the importance of striving for an adequate governance framework (Sartor et al. 2014). In addition, this article can provide a valuable contribution for the development of an adequate governance framework for EE, which should be in line with the principles for good governance, including effectiveness, transparency, accountability, legitimacy, policy coherence, flexibility, and reliability (Bonn et al. 2015; Eurelectric 2015; Turner 2015).

The organisation of the paper is as follows. The "Energy efficiency governance" section presents and 
discusses the concepts of governance and its application on the EE field, as well as EU policies and measures; the "Data collection and analysis" section presents the selected indicators and analysis conducted; the "Results and discussion" section unveils the results of the governance analysis and Member State cluster distribution; and the "Conclusion" section synthesises the implications of the research conducted, limitations faced, and presents pathways for future developments.

\section{Energy efficiency governance}

The focus on EE governance has been increasing over the years, mostly due to the growing awareness that stronger efforts are necessary to deliver the established targets. This is in line with the wide ranging energy governance concerns discussed by Florini and Sovacool (2009), which present governance as the processes undertaken and effort of a group of people to achieve a desired outcome. However, despite this awareness of the need for stronger governance, the issues of energy and EE governance have remained mostly undiscussed by relevant stakeholders (Karlsson-Vinkhuyzen et al. 2012), and when those are part of the argument, the outcome is often vague and unspecified as for action frameworks and specifications of the actions needed (Meyer-Ohlendorf et al. 2015).

Despite the acknowledged lack of momentum regarding EE governance aspects, the International Energy Agency (IEA 2010) and Jollands and Ellis (2009) presented the term EE governance as the use of political influence, organisations, and resources by decision making agents to deliver greater levels of EE improvements. This definition provides a broad scope for EE governance, through which three different building blocks are identified as contributors to increased energy efficiency. Firstly, the role of political influence can result from the guidance given through political mandates and reflected in public policies. Secondly, the role of organisations that contribute for products and services linked directly or indirectly to advance energy efficiency across sectors. Lastly, the role of resources can be acknowledged as the result of coordinating political influence and organisation interests. Nonetheless, it is also important to consider that despite the complementarities of political influence and organisations to allocate resources towards energy efficiency improvements, oftentimes conflicting interests between policymakers and organisations can result in slower or less adequate actions taken by decision makers. This can consequently have a negative impact on the support structures available. Given this, it is relevant that political influence and organisational interests are coordinated to ensure that different institutions have reinforcing motivations to allocate resources towards growing levels of energy efficiency.

Notwithstanding, the presented concept is a valuable contribution to stimulate researchers, policymakers, and other relevant stakeholders to look at EE and its governance through a clearer lens, with a set of defined building blocks. The importance of the initiative taken by the IEA and Jollands and Ellis, to promote the discussion around EE governance, was further enhanced as global EE governance was considered diffuse, unstructured, and hardly covered in the literature (Gupta and Ivanova 2009), hence undermining its potential contribution for energy security, economic development, environmental protection, and energy poverty mitigation.

Further emphasis on the importance of governance within climate and energy policies, hence covering energy efficiency, has been triggered through the new goals for 2030 at the EU level (Meyer-Ohlendorf et al. 2015). Herein, the discussions associated with energy efficiency governance have mainly focused on effectiveness, compliance, planning, and reporting. In this context, the aims of the governance framework being developed are seen as a driver to (Nesbit 2014) increase the possibility to meet the set targets, enhance indirect impacts such as job creation and energy security, and ensure that the framework to be developed provides also a pathway for the 2050 decarbonisation goals (IEA 2014; Ringel et al. 2016). Therefore, the different perspectives on EE governance covering its concept, status, and importance place it as an evolving concept shaped by current policies and evaluation of progress.

Considering this, a practical application of the energy efficiency governance concept can be observed when looking at the EE policy context in the EU, which engages EU-level institutions, Member State governments, citizens, and private sector players to deliver EE improvements. To do so, the EU implements strategies, directives, and programmes with different levels of reach and scope for EE policies to succeed.

\section{EE actions in the EU}

The various levels of intervention from the EU side can be summarised through the following figure (Fig. 1). We 


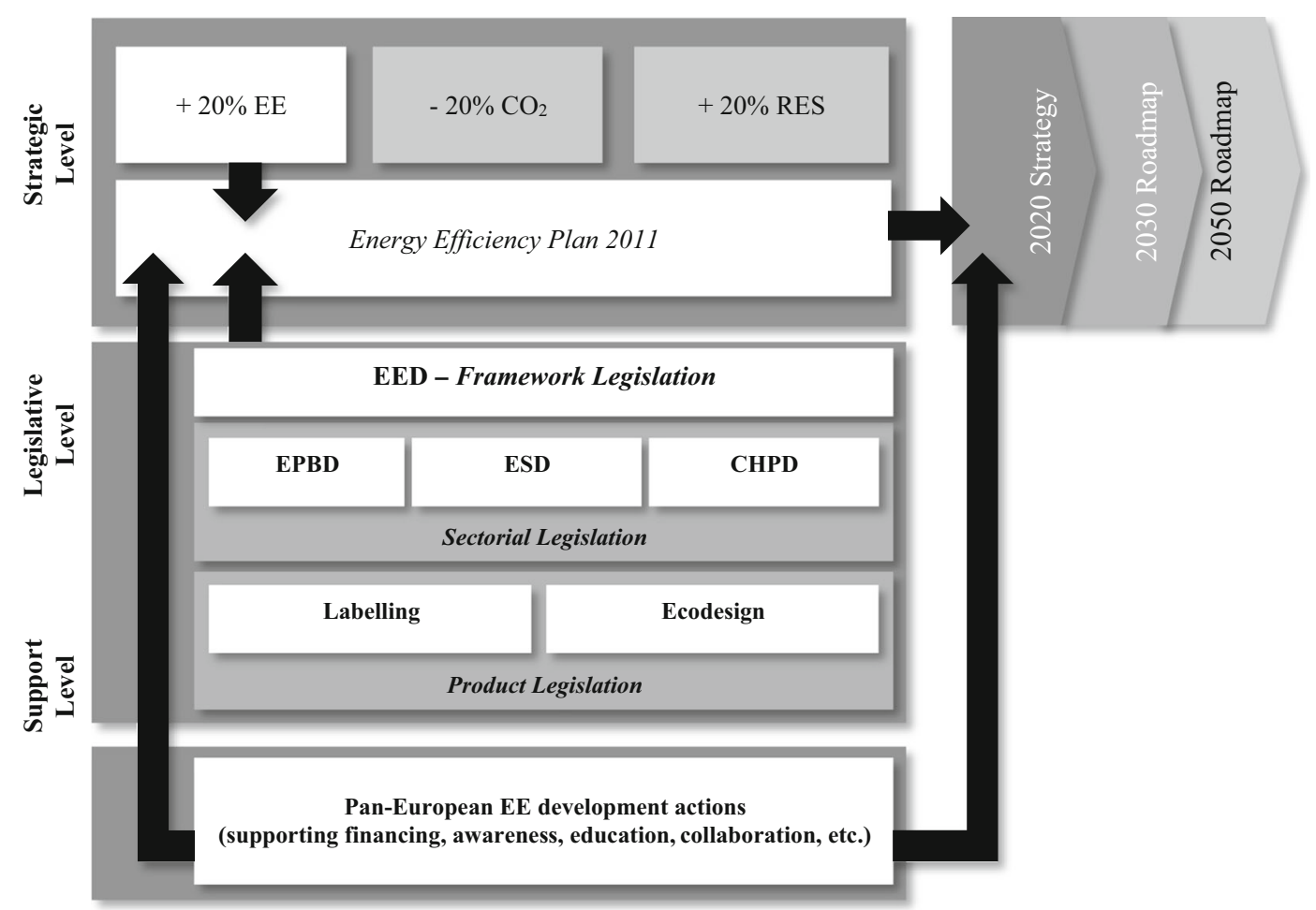

Fig. 1 European Union EE governance development scheme. $C O 2$ carbon dioxide, $R E$ renewable energy, $E P B D$ energy performance of building directive, ESD energy service directive, $C H P D$ combined heat and power directive

organise them, ordered by scope, from broader to narrower in strategic actions, legislative actions, and support actions.

The different levels of action presented in Fig. 1 are part of an interconnected governance development scheme, which aims at ensuring the necessary mechanisms for delivering the energy- and climate-related targets.

\section{Strategic level}

At the strategic level, the EU has been implementing a range of policy roadmaps and communications that create a framework for action, and enable new directives and regulations, as well as support actions to be designed as supporting mechanisms for these strategies. The following table (Table 1) presents the existing strategic orientations from 2020 to 2050 for climate and energy.

The strategic level actions in Table 1 serve as guidelines for what should be achieved in the future in terms of climate and energy goals. These high-level strategies shape a framework for the creation of laws that enforce actions and the implementation of policies in a defined time frame and consistent with a set of requirements deemed adequate for the policy objectives in place.

\section{Legislative level}

In terms of the laws created, driven by the strategic actions in the area of EE, the EED is the key legislative instrument, enacted in 2012 which is more ambitious, when compared to the previous Energy Services Directive (European Union 2012b). The new instrument goes beyond energy services and end-uses, including actions concerning EE in generation, transmission, and distribution of energy. The measures implemented by this Directive include (European Commission 2011c, d) the following:

- Energy-saving schemes across Member States: energy distributors and retail energy sales companies must save $1.5 \%$ on their energy sales every year in volume of energy supplied to costumers. Delivered through EE measures targeting: heating systems, window replacement, and roof insulation implemented on final energy users' facilities. 
Table 1 Strategic level action for EE in the EU

\begin{tabular}{lcc}
\hline Strategic level action & Main goals/ambitions & References \\
\hline Europe 2020 20-20-20 & $\begin{array}{c}20 \% \text { reduction of primary energy consumption, } \\
20 \% \text { increase in renewable energy, and 20\% } \\
\text { reduction of GHG emissions }\end{array}$ & $\begin{array}{c}\text { European Commission (2010, 2011a) } \\
\text { and European Union (2012a) }\end{array}$ \\
$\begin{array}{c}40 \% \text { reduction of GHG emissions, 27\% increase } \\
\text { in renewable energy, and 30\% reduction of } \\
\text { primary energy consumption } \\
\text { and energy policies }\end{array}$ & $\begin{array}{c}\text { European Commission (2013b, } \\
\text { e, 2014a, d, 2016a) }\end{array}$ \\
$\begin{array}{ll}80-95 \% \text { reduction of GHG emissions } \\
\text { Europe 2050 roadmap }\end{array}$ & & $\begin{array}{c}\text { European Commission (2011c), } \\
\text { European Union (2013), and } \\
\end{array}$ \\
\end{tabular}

- The public sector must be responsible for the uptake of energy-efficient products and services, whilst improving their own energy savings through the renovation of $3 \%$ of the building stock every year.

- Consumer access to accurate real-time data on their energy consumption and their history, empowering them to manage better their use. In addition, more detailed and clear bills will provide information on real consumption for users to track their evolution.

- Incentives for small and medium enterprises (SMEs) to conduct energy audits and implement best-case practises, whilst supporting large companies to increase their energy usage awareness and unlock potential energy savings.

- Efficiency in generation through the monitoring of efficiency levels of new energy generation plants, and the definition of national heating and cooling strategies to avoid energy waste.

- Ensure that EE is considered by energy regulators on decision making, aiming at efficiency gains in energy transmission and distribution.

Notwithstanding its overarching design, oriented towards increased levels of EE improvements, the EED was established in the context of the 2020 climate and energy agenda. Therefore, in light of the new binding target of minimum $30 \%$ EE improvements in 2030, the EC has presented a set of proposals for amending the current directive to be in line with the post-2020 policy roadmap (European Commission 2016a). These were communicated as part of the Clean Energy for All Europeans policy package, released in late 2016 (European Commission 2016b). The proposed adjustments focus on providing stimuli for alternative measures to save energy, which can complement Energy Efficiency Obligation Schemes. In addition, the proposals aim to clarify and simplify how energy savings are calculated. These changes are proposed to facilitate the transition from the current EED to a legislative instrument that is in line with the renewed climate and energy agenda (European Commission 2016e).

In terms of sectorial legislation, the energy performance of building directive (EPBD) promotes cost-effective improvements in the energy performance of buildings (European Union 2010b). In line with the amendments being proposed to the EED, the EPBD counts also with a set of proposals for adjustment to stimulate the use of information and communication technologies to increase building's efficiency, reframe or remove provisions that have underperformed, and reinforce the intertwined relationship between increased building renovation rates, unlocking funding, and increasing building energy performance certificates (European Commission 2016a, d). These proposals aim to reinforce the Directive's effectiveness and facilitate implementation at the national level by Member States (European Commission 2016a).

The ESD was the predecessor of the EED and focused on efficiency improvement in energy services and end-uses, now repealed (European Union 2006), and the CHPD supported the promotion and development of efficient cogeneration of heat and power, now repealed (European Union 2004).

In addition, product legislation has also been developed through which the Labelling Directive establishes the framework for end-user information on the energy use of products to support more energy-efficient choices (European Union 2010a), and the Ecodesign Directive defines the necessary framework for the development of energy-related products with an adequate level of environmental performance, including energy efficiency (European Union 2009). Notably, and similarly to the 
previous cases, the EC has also introduced a set of proposals for adjusting these instruments (European Commission 2016a). These include establishing an Ecodesign Working Plan, to consider new product groups and how ecodesign can contribute to the circular economy; facilitate industry self-regulation as alternative to legislation; revise minimum energy efficiency requirements for air heating and cooling technologies; and further standardise ecodesign measures (European Commission 2016c). These proposals aim to contribute to sustained support for increased energy efficiency improvements in EU products (European Commission 2016a).

Additionally, to the legislative and strategic actions mentioned, the EU develops a range of support actions that consist in programmes and joint actions often for more specific parts of the policy roadmaps in place.

\section{Support level}

Support actions represent efforts to remove market barriers and support the delivery of planned energy savings. These actions are designed to boost information sharing, training activities, and financial support enabling a broader reach of the necessary evolution on practises and technologies across the EU that contributes to improvements on EE. The following measures are an illustrative sample of the support actions in the field of EE:

- EU ENERGY STAR Programme, for labelling energy-efficient office equipment, based on an agreement between the US government and the EU (European Commission 2013a).

- GreenLight Programme, designed to engage non-residential consumers on the installation of energy-efficient lighting technologies (European Commission 2013d).

- GreenBuilding Programme, designed to motivate non-residential building owners to adopt energy-efficient measures (European Commission 2013c).

These initiatives consist on actions that beyond their direct contribution to EE development represent also efforts to improve energy security and environmental quality, such as carbon dioxide emission reduction and renewable energy source integration, and clean technology deployment. These initiatives have the advantage to support the implementation at Member State level of the strategies shaping the future of the energy system in Europe, through a diverse range of market actors (i.e. energy agencies, governments, SMEs, and energy associations) ensuring that the market is both being developed and that schemes to support this development exist.

These EE actions in the EU now described unveil the different levels at which the EC and the EU promote actions to deliver EE across Member States. Insofar, we have presented each of the levels of action (i.e. strategic level actions, legislative level actions, and support level actions) in a general way. However, we deem these different levels as interrelated, consequently having an impact in the other levels of action. A sample of the possible interactions is presented in the following table (Table 2).

For instance, an action at the strategic level can trigger a new law or support programme, and a support programme may for instance lead to the understanding that new barriers for EE need to be tackled through additional strategies or legislation.

Governance analysis methodology and frameworks

The literature associated with EE governance analysis methodologies and frameworks is scarce as discussed by Gupta and Ivanova (2009); however, there has been an increase in the contributions recognising the value of EE governance (Bazilian et al. 2014), which represent an effort to establish a level playing field around governance related to EE aspects. For instance, Delina (2012) presented a governance analysis framework based on different case studies in order to assess existing capacities, motivations, and intervention dimensions within EE-related entities, therefore representing a more descriptive rather than analytical contribution. Focused on EE governance in electricity markets in Turkey, Tasdoven et al. (2012) presented an analysis focusing on governance approaches departing from the government and analysed the success of privatisation and regulation as governance tools, and proposed the implementation of grants and provision of public information as additional governance improvement approaches for the reduction of the inefficiencies associated with electricity distribution. A complementary contribution is that of Golubchikov and Deda (2012), which analysed the wide-spectrum policy framework proposed by the United Nations Economic Commission for Europe 
Table 2 Interactions across levels of EE action in the EU

\begin{tabular}{|c|c|c|}
\hline Level of action & Description & Possibilities for interactions across levels of action \\
\hline Strategic level & $\begin{array}{l}\text { Strategies for the energy system ensure } \\
\text { long-term energy security development } \\
\text { and sustainable evolution of technology } \\
\text { and practises (e.g. Energy Strategy 2020, } \\
\text { Low-Carbon Roadmap 2050) }\end{array}$ & $\begin{array}{l}\text { Interaction at the legislative level } \\
\text { The definition of new EE targets and frameworks } \\
\text { requires the development of legislative acts to } \\
\text { support their delivery and correct implementation. } \\
\text { (e.g. the EED supporting the Energy Efficiency } \\
\text { Plan 2011) } \\
\text { Interaction at the support level } \\
\text { Strategic roadmaps outline support actions to } \\
\text { boost the expected results to ensure that targets } \\
\text { and measures are reached (e.g. Horizon } 2020 \\
\text { Programme) }\end{array}$ \\
\hline Legislative level & $\begin{array}{l}\text { Legislative acts in the EU (e.g. directives } \\
\text { and regulations) define binding measures } \\
\text { and targets that must be transposed by } \\
\text { Member States, creating frameworks } \\
\text { and schemes across sectors to increase EE }\end{array}$ & $\begin{array}{l}\text { Interaction at the strategic level } \\
\text { Implementing law on EE supports both the } \\
\text { accomplishment of middle and long-term strategies } \\
\text { and the necessary Member State contributions } \\
\text { for a sustainable energy future in the EU } \\
\text { Interaction at the support level } \\
\text { Existing or new legislative acts on EE benefit } \\
\text { from support actions by ensuring communication, } \\
\text { collaboration, and structures for Member States } \\
\text { to comply with the law (e.g. EU Energy Star } \\
\text { Programme) }\end{array}$ \\
\hline Support level & $\begin{array}{l}\text { Support actions and programmes ensure } \\
\text { that efforts are made across the EU to } \\
\text { tackle barriers to the implementation of } \\
\text { EE strategies, through broader or more } \\
\text { targeted actions (e.g. GreenLight } \\
\text { Programme) }\end{array}$ & $\begin{array}{l}\text { Interaction at the strategic level } \\
\text { Support level initiatives contribute to the definition } \\
\text { or refinement of new and existing strategies for } \\
\text { the energy system, through the insights resulting } \\
\text { from Member State realities } \\
\text { Interaction at the legislative level } \\
\text { Through the development and implementation of } \\
\text { support programmes, insights arise to improve, } \\
\text { amend, or repeal legislation on EE, ensuring that } \\
\text { the EE potential realised is maximised }\end{array}$ \\
\hline
\end{tabular}

(UNECE) for the housing sector, which aggregates EE governance and finance and measures its success through organisational leadership, administrative bodies, planning, management, and monitoring capacities; financial incentive existence; housing management capacities; and utility services and energy prices, as enablers to promote greater levels of EE. Moreover, the works of Steuwer (2012) and Bertoldi and Rezessy (2009) analysed EE governance in Europe, focusing on White Certificate Instruments and their application in different contexts. An additional analysis framework has also been presented by Jollands and Ellis and the IEA (Jollands and Ellis 2009; Jollands et al. 2009), focusing on multi-level governance (Davies 2006); the analysis framework considers a horizontal dimension, at the same government level, and a vertical dimension, embodying different levels of interaction. From an EU-wide project, Energy Efficiency Watch (Schüle et al. 2013), it is possible to observe an EE governance analysis that considers long-term targets and strategic aspects, diversity of stakeholders involved in promoting EE, energy agencies involved, overall EE coordination and finance, enabling framework for EE services, horizontal measures, and monitoring, reporting, and verification capacities. Similarly, a more recent EU-wide project, multiEE (multiEE 2015), developed a multi-level governance analysis across Member States by considering the quality and consistency of existing policies, as important indicators to strengthen the governance framework, 
and further contribute to improved policy planning and implementation. In addition, Ringel et al. (2016) developed an analysis of energy efficiency policy impacts in Germany, as a means to enhance the need for a reinforced energy efficiency governance framework, in addition to more ambitious policies.

The various approaches to EE governance analysis methodologies and frameworks present diverse perspectives, analysis dimensions, levels of analysis, and aggregate different aspects. However, given the flexibility of the term governance, all can be deemed as correct and valuable, which increases the complexity to understand what are the most adequate approaches to be used when conducting governance analyses. Nonetheless, it is crucial that further contributions are disclosed to enable the body of knowledge on EE governance to evolve and contribute to a strong EE analysis framework that supports the delivery of the ambitious EE targets set for the upcoming years. These future contributions for governance analysis should consider both the more specific governance-related applications used for the EE field, such as those presented in this section, as well as the more general governance-related contributions in the literature. An example of this includes the work of Gisselquist (2014), which proposes a set of questions to guide the process of defining relevant governance indicators.
Based on the literature review presented regarding the different applications of EE governance analyses, the following synthesis table was structured (Table 3). This allows for a better comparison of the different possible approaches for analysing EE governance.

The governance capacity analysis presented in this paper is driven by the EC recent focus on strengthening the existing governance framework for climate and energy policies in the EU. Given this, for improving the existing capacities, it is important to analyse their status. In line with this, it is relevant to highlight that the framework designed by the EU in terms of EE actions establishes a set of measurable indicators, which enable the measurement of the level of compliance from the Member States to EU-level actions. Considering these defined areas of analysis and the availability of data to conduct the analysis, the methodology used in this paper is that of Jollands and Ellis (2009), which enables the assessment of the level of compliance in different dimensions at different levels (i.e. local, national, international). The authors of the methodology define the foundations for governance, as the necessary resources required to establish a governance system, consisting of institutional structures, financial resources, human capacity, and political support. These dimensions provide the direction to the analysis to be performed in

Table 3 EE governance approach synthesis

\begin{tabular}{|c|c|c|c|}
\hline Analysis dimension & Level of analysis & Focus of analysis & Reference \\
\hline Specific case studies & $\begin{array}{l}\text { Individual entities/ } \\
\text { companies }\end{array}$ & Assessment of motivations, capacities, and interventions & Delina (2012) \\
\hline $\begin{array}{l}\text { Turkish electricity } \\
\text { market }\end{array}$ & Country & $\begin{array}{l}\text { Assessment of the impact of privatisation and government } \\
\text { regulations as governance tools }\end{array}$ & $\begin{array}{l}\text { Tasdoven et al. } \\
\text { (2012) }\end{array}$ \\
\hline $\begin{array}{l}\text { European housing } \\
\text { sector }\end{array}$ & $\begin{array}{l}\text { Regional } \\
\quad \text { (i.e. European level) }\end{array}$ & $\begin{array}{l}\text { Assessment of different governance enablers, including } \\
\text { organisational, leadership, and planning capacities, } \\
\text { amongst others }\end{array}$ & $\begin{array}{l}\text { Golubchikov and } \\
\text { Deda (2012) }\end{array}$ \\
\hline $\begin{array}{l}\text { European White } \\
\text { Certificates }\end{array}$ & $\begin{array}{l}\text { Regional } \\
\quad \text { (i.e. European level) }\end{array}$ & $\begin{array}{l}\text { Assessment of different governance aspects of White } \\
\text { Certificates' implementation in different national contexts } \\
\text { in the EU }\end{array}$ & Steuwer (2012) \\
\hline Cross-sectoral & $\begin{array}{l}\text { Multi-level (i.e. from local } \\
\text { to international level) }\end{array}$ & $\begin{array}{l}\text { Assessment of different governance dimensions, across } \\
\text { sectors and across local, national, and international regions }\end{array}$ & $\begin{array}{l}\text { Jollands and } \\
\text { Ellis (2009) }\end{array}$ \\
\hline $\begin{array}{l}\text { Various dimensions } \\
\text { across sectors }\end{array}$ & Country & $\begin{array}{l}\text { Assessment of governance capacities including targets and } \\
\text { strategic aspects, stakeholders engaged, and energy agencies } \\
\text { involved, amongst others }\end{array}$ & Schüle et al. (2013) \\
\hline European policy & $\begin{array}{l}\text { Regional (i.e. European } \\
\text { level) }\end{array}$ & $\begin{array}{l}\text { Assessment of the quality and consistency of policies across } \\
\text { EU Member States }\end{array}$ & multiEE (2015) \\
\hline National policy & Country & $\begin{array}{l}\text { Assessment of policy impacts as a proxy to enhance the } \\
\text { need for a more robust governance framework }\end{array}$ & Ringel et al. (2016) \\
\hline
\end{tabular}


the following section. We acknowledge these governance dimensions as different groups of capabilities existing at each Member State for which we will analyse the level of existing capacity for each selected indicator within these dimensions.

Jollands and Ellis (2009) present their methodology as follows (Fig. 2).

The governance analysis to be presented for the EU Member States is based on an adaptation of the above presented methodology in order to be able to aggregate a set of indicators into an analysis that provides relevant outputs on the status of EE governance capacities. The level of the analysis is international (i.e. EU level), as indicators from the 28 Member States were selected, collected, and analysed. The following section presents the main analyses conducted for the selected dimensions within the defined framework. The reason for the selection of this methodology is based on the diversity of indicators, which combine complementary dimensions of EE governance and are relevant to determine strengths and weaknesses in EE governance. In line with this, the selected methodology enables the analysis of the exiting institutional, human, financial, and political support to deliver EE as a measure of EE governance. These capacities, as stated by Kempe (2011), represent the foundations for the planning, implementation, and achievement of development objectives, which in this case are EE developments. In addition, the methodology selected enables different levels of adaptation to suit data availability, therefore representing a flexible framework, which is important to increase the existing knowledge about EE governance across EU Member States. Moreover, considering the existing approaches for EE governance analysis mentioned previously, the selected methodology is the most suitable for the EU-level analysis that we conduct herein.

\section{Data collection and analysis}

To develop the energy efficiency governance analysis, a data collection effort was conducted to identify potential sources of information. Through this process, the most relevant databases devoted to energy efficiency-related aspects were considered, which are the ODYSSEE MURE database, which includes data on energy efficiency progress, evaluation of policies, and implemented legislation at the EU and national levels; the IEA Energy Efficiency Policies and Measures database, which includes information on policies taken or planned; and the World Energy Council Energy Efficiency Policies and Measures database, which includes country-level indicators and policy case study analyses, in addition to the information in reports published by the European Commission.

Considering the possible sources of information, the data for analysis was collected from the World Energy Council Database for Energy Efficiency Policies and
Fig. 2 Schematic of governance dimensions. Adapted from Jollands and Ellis (2009)

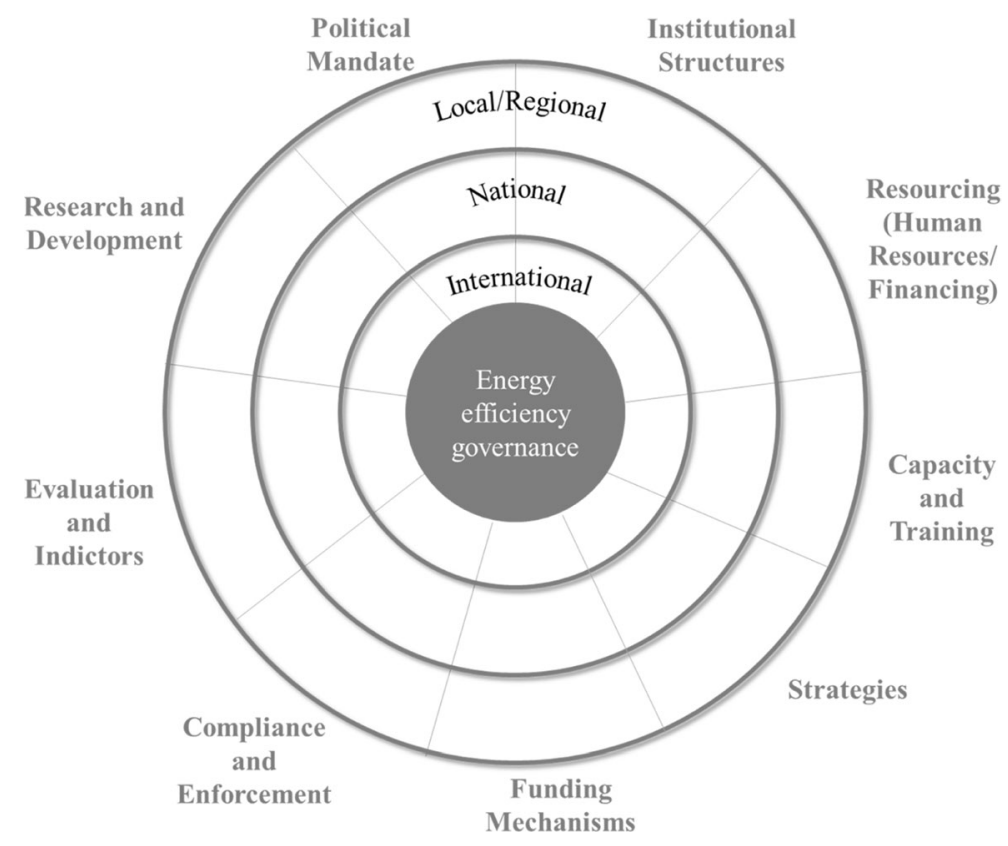


Measures (World Energy Council 2015) and EC reports (European Commission 2014e, 2015b). The World Energy Council database was selected as an adequate data source given that it is developed by ADEME and ENERDATA and it aims to aggregate the data available from both the ODYSSEE MURE and IEA databases. The database results from both a survey and a literature review to identify energy efficiency measures and policies. Through the available data from the selected sources, it is possible to analyse a set of dimensions from the governance framework (see Fig. 2). The indicators collected enable the development of an analysis covering the four foundation dimensions of governance presented by Jollands and Ellis (2009). The following table (Table 4) presents the indicators included within each dimension for analysis.

The data analysis process presented in this paper is two staged. Firstly, the information obtained is categorised considering the level of compliance with the specific governance indicator being analysed. The analysis of the indicators within the institutional structures, financial capacity, and political support dimensions within each Member State are categorised according to the following criteria: (i) complies with the indicator, (ii) does not comply with the indicator, (iii) no information available on the indicator, and (iv) ongoing effort to comply with the indicator.

For the indicators within the human capacity dimension, the categorisation is as follows: (i) human resources allocated, (ii) no human resources allocated, and (iii) no information available on the indicator.

The categorisation process enables the application of the governance analysis methodology presented that has as main output an aggregated analysis of the status of EE governance capacities within the EU.

The second stage of the governance capacity analysis consists on the development of governance clusters to provide a perspective about each Member State performance. This complements the EU-level analysis presented through the application of the Jollands and Ellis (2009) framework on the first stage. The distribution of Member States through the clusters is obtained from the allocation of points, which are assigned according to the level of compliance attributed on the first stage of the analysis. The points given to each Member State for this purpose are presented in the following table (Table 5).
The outputs obtained from the aggregation of the indicator set collected are presented, ${ }^{1}$ providing an overview on the existing capacities at each Member State ${ }^{2}$ for each governance capacity indicator.

Institutional structures

In terms of institutional structures, the governance capacity indicators selected enable the analysis of the existing organisations focused on the promotion and governance of EE in each Member State. The following graphs in Fig. 3 present the general results for the EU-28.

In this context, ministry departments for EE are government institutional structures that have devoted resources to promoting energy efficiency, either as an independent department or as part of other government departments. National energy agencies are non-governmental bodies promoting $\mathrm{EE}$ at the national level, whilst local energy agencies are non-governmental institutions promoting $\mathrm{EE}$ at the community level. In terms of institutional structures, the energy agencies at national and local level are well implemented throughout the EU, with 23 and 26 Member States with these institutional structures, respectively. In contrast with this, only 15 Member States have a Ministry department focused on EE issues.

Financial capacity

The financial capacity dimension was analysed by searching for the existence of dedicated EE funding at the Member State level to promote and support EE improvements (Fig. 4).

The financial capacity analysis presents that specific funding for EE exists only in 18 of the Member States.

\section{Human capacity}

The dimension associated with human capacity is analysed through the data available on the allocation of human resources in the different types of organisations analysed in the institutional structure dimension. The following table (Fig. 5) aggregates the information

\footnotetext{
${ }^{1}$ A dataset provided as Online Supplementary Material presents the Member States included in each group of the analyses presented for the four dimensions analysed

${ }^{2}$ Abbreviations used: n.i., no information available
} 
Table 4 EE governance capacity indicators collected and analysed

\begin{tabular}{|c|c|c|}
\hline Dimension & Indicator & Source \\
\hline Institutional structures & $\begin{array}{l}\text { National energy agency } \\
\text { Ministry department for EE } \\
\text { Local energy agencies }\end{array}$ & \multirow[t]{4}{*}{$\begin{array}{l}\text { World Energy } \\
\text { Council (2015) }\end{array}$} \\
\hline Financial capacity & Dedicated EE funds & \\
\hline Human capacity & $\begin{array}{l}\text { National energy agency } \\
\text { Ministry department for EE } \\
\text { Local energy agencies }\end{array}$ & \\
\hline \multirow[t]{9}{*}{ Political support } & $\begin{array}{l}\text { National EE programmes with targets } \\
\text { Energy law with EE targets }\end{array}$ & \\
\hline & $\begin{array}{l}\text { Dedicated EE law } \\
\text { EPBD transposition on } 22 \text { July 2014, due } 09 \text { July } 2012\end{array}$ & \multirow[t]{8}{*}{$\begin{array}{l}\text { European Commission } \\
\quad(2014 \mathrm{a}, 2015 \mathrm{~b})\end{array}$} \\
\hline & EPBD cost-optimal calculation report on 22 July 2014, due 21 March 2013 & \\
\hline & EPBD near-zero energy building report on 22 July 2014, due 04 March 2014 & \\
\hline & EED targets presented on 16 July 2014, due 30 April 2013 & \\
\hline & EED building renovation strategy on 16 July 2014, due 30 April 2013 & \\
\hline & $\begin{array}{l}\text { EED EE obligation schemes or alternative programmes on } 16 \text { July } 2014 \text {, } \\
\text { due } 05 \text { December } 2013\end{array}$ & \\
\hline & $\begin{array}{l}\text { EED third round of National EE Action Plans (NEEAPs) delivered on } \\
16 \text { July 2014, due } 30 \text { April } 2013\end{array}$ & \\
\hline & EED transposition on 16 July 2014, due 05 June 2014 & \\
\hline
\end{tabular}

on the existence of human resources allocated to the institutional structures.

Human resources allocated to the organisations engaged on promoting $\mathrm{EE}$ at national or regional level, through energy agencies, or at governmental level through ministry departments for EE vary widely. Therefore, in order to avoid a misleading analysis, the human capacity indicators were organised by categories, as described previously. Through this approach, Member States are categorised as compliant with the governance indicator when any number of persons are Table 5 Governance point assignment method

\begin{tabular}{lc}
\hline Criteria & Points assigned \\
\hline Institutional, legislative, and financial Dimensions & 1 \\
Complies with the indicator & -1 \\
Does not comply with the indicator & 0 \\
No information available on the indicator & 0.5 \\
Ongoing effort to comply with the indicator & \\
Human capacity & 1 \\
Human resources allocated & -1 \\
No human resources allocated & 0 \\
No information available on the indicator & \\
\hline
\end{tabular}

allocated to the organisations considered for the analysis.

\section{Political support}

Regarding political support, the analysis is based on the level of compliance with a set of EU Directives, the EED (European Union 2012b) and the EPBD (European Union 2010b). These are relevant as they represent both the EU framework legislation for EE, the EED, through which efficiency improvements from generation to end-uses are promoted, and the specific building sector EE legislation, the EPBD, through which cost-effective efficiency improvement are sought, as a sector with significant potential. These legal instruments are considered in combination with an additional set of indicators that provide a general perspective on the existing political structures to advance EE.

The results presented above (Fig. 6) show most of the indicators collected for the analysis. From the outputs obtained, the most critical is the status of implementation of the EED by Member States; by now, available data shows that only five Member States have the overarching 


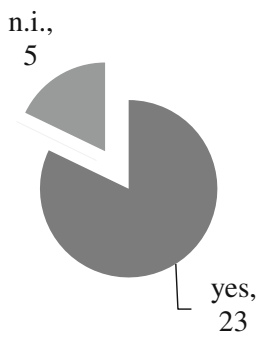

Existence of national energy

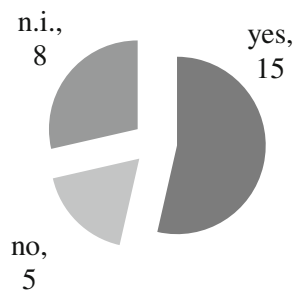

Existence of ministry department

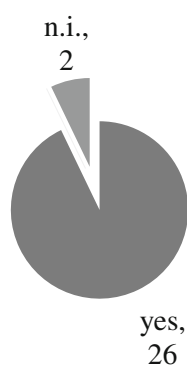

Existence of local energy agencies

Fig. 3 Institutional structure analysis results

EE legislative instrument transposed into national legislation. However, despite the existing failure to transpose the EED on time, all Member States have presented their EE targets to meet by 2020, as required, as well as have all presented the EE obligation schemes or alternative initiatives to foster the improvement of EE levels.

In addition to the political support provided by the EU Directives, it is possible to observe that 27 Member States have national EE programmes with specific targets. However, when looking at legal instruments with targets, only 13 Member States have energy law with defined EE targets, whilst 15 Member States have dedicated EE law.

The outputs herein presented are aggregated and discussed in the following section providing the main results of the research process. The research framework for EE governance analysis presented in Fig. 2 is now depicted in an adapted version according to the governance dimensions and indicators considered. Moreover, the developed governance clusters are disclosed. This provides a basis to better understand the regions in the $\mathrm{EU}$, where more effort is required for the development of the necessary governance capacities to ensure their necessary contributions to achieve the set EE targets.

\section{Results and discussion}

The two-stage analysis developed is valuable in terms of the insights it provides, enabling a more detailed understanding of the existing EE governance capacities in the EU.

The first stage of the analysis, based on the application of the governance framework of Jollands and Ellis (2009) adapted to the available indicators, provides EU-level information on the current capacities within the analysed dimensions. This is relevant to provide policymakers with the areas where more action is needed for future development of the new governance framework for climate and energy policies.

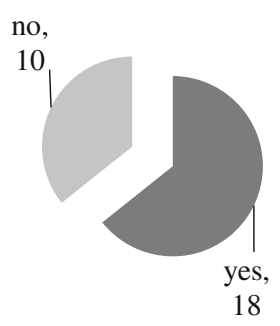

Existence of dedicated EE funding.

Fig. 4 Financial capacity analysis results 


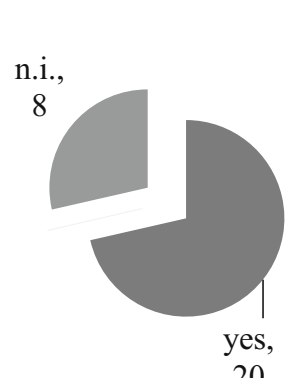

20

Human resources assigned to the national energy agency

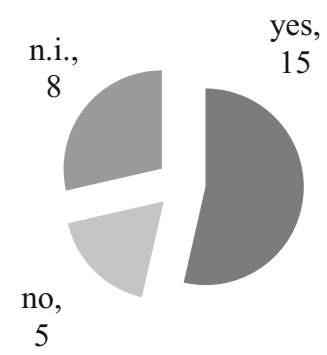

Human resources assigned to the ministry department for EE

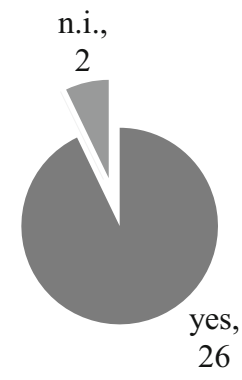

Human resources assigned to the local energy agencies

Fig. 5 Human capacity analysis results

The second stage of the research, based on the distribution of Member States across clusters according to their performance in terms of the EE governance capacities (see Table 5 for point assignment method), provides complementary information. From the results obtained, policymakers' can access a broad-level perspective on the status of EE governance capacities in each Member State. In addition, the clusters provide Member States with a perspective on their positioning in the EU-wide framework.

Governance analysis framework results

The governance analysis framework applied in this paper is based on different dimensions, for which the individual results were presented in the previous section; the aggregated results enable a global overview on all the governance capacity indicators analysed, presented through the following graph (Fig. 7).

The results shown above (Fig. 7) are presented in terms of number of Member States of the EU-28 that are complying with the governance indicator in each dimension (e.g. In the financial capacity dimension, for the dedicated EE funds, 18 Member States have a dedicated fund, therefore complying with the indicator).

From this analysis, it is possible to observe that in terms of institutional structure and human capacity, the EU presents a significant potential for improvement. Despite the existing structures, the results show that only 23 Member States have national energy agencies and 15 Member States have ministry departments for
EE. Local energy agencies present the best outcome with 26 Member States complying with the indicator. This analysis of the existing structures reflects a similar situation in the human capacity dimension as the data for human resources allocated to EE organisations is for the same institutions analysed in the institutional structure dimension.

In terms of financial capacity, 18 Member States have dedicated EE financing schemes, which are either funded through the national public budget or through specific taxes for climate and energy-related action.

The political support dimension presents positive results associated with the EPBD transposition, with 22 Member States with the directive transposed into their national law. However, the situation associated with the EED is significantly weaker, with only five Member States with the directive transposed. The EED was designed to increase EU efforts towards a more energy-efficient economy; the failure to adopt the measures proposed will have a direct impact on the ability to deliver the planned goals, as well as on ensuring a wideranging collaborative effort for a more efficient use of energy resources.

From the indicator set collected, the political support dimension provides a wider vision given the greater availability of information.

In line with the above, the EC (European Commission 2014d) is aware of the need for a stronger governance framework and as part of the 2030 energy and climate agenda has presented the ambition to improve the EE governance process existing in the 2020 

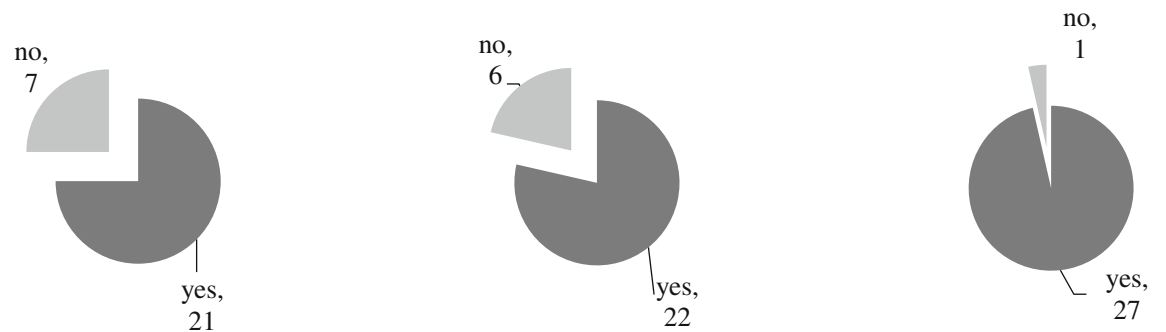

EED 3rd Round of NEEAPS delivered

EED Building renovation strategy

National EE programmes with targets

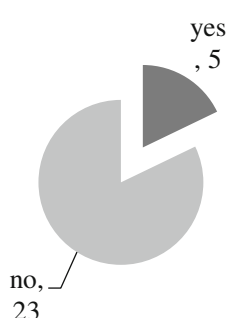

23

EED Transposition

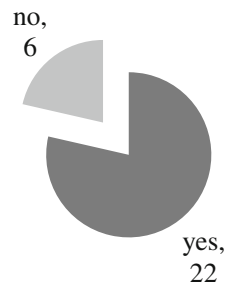

EPBD Transposition

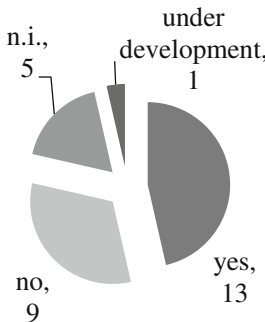

Energy law with EE targets

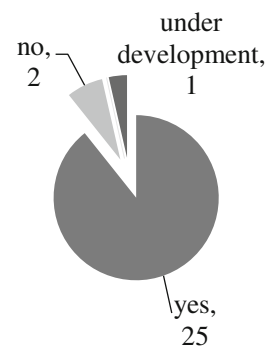

EPBD Cost-optimal calculation report

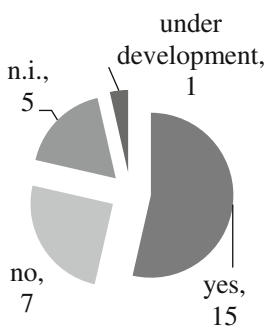

Dedicated EE law

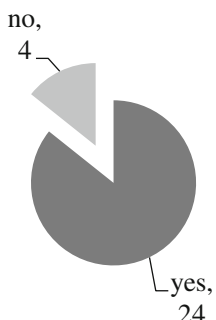

EPBD NZEB report

Fig. 6 Political support analysis results

energy and climate framework, towards a more consolidated and supportive system, further enhanced by the Energy Union mandate (European Commission 2015c). Through this, the EC envisions to deliver the EU energy and climate agenda goals, improve Member States' approaches to EU policy implementation, stimulate the competition and integration of energy markets, and reduce the uncertainties related to the set targets to drive more investment. The proposed governance framework improvement is supported by a three step process (European Commission 2014b), whose main feature is related to its overarching nature covering both the planning process and providing further support in the post-planning period, ensuring the adequacy and attainability of the developed plans.
The EC can consider the results obtained from the EU-wide analysis, herein presented, as a source of inputs for further developing an improved governance framework. For instance, the impact of the different dimensions and their possible contribution for delivering the established EE targets could be assessed. Establishing the link between governance capacities and actual energy efficiency performance at the EU level can be valuable to understand how much do governance capacities contribute to actual EE improvements, which according to recent discussions is directly related (Bonn et al. 2015; Eurelectric 2015; Meyer-Ohlendorf et al. 2015). Therefore, considering governance capacities and also their evolution 


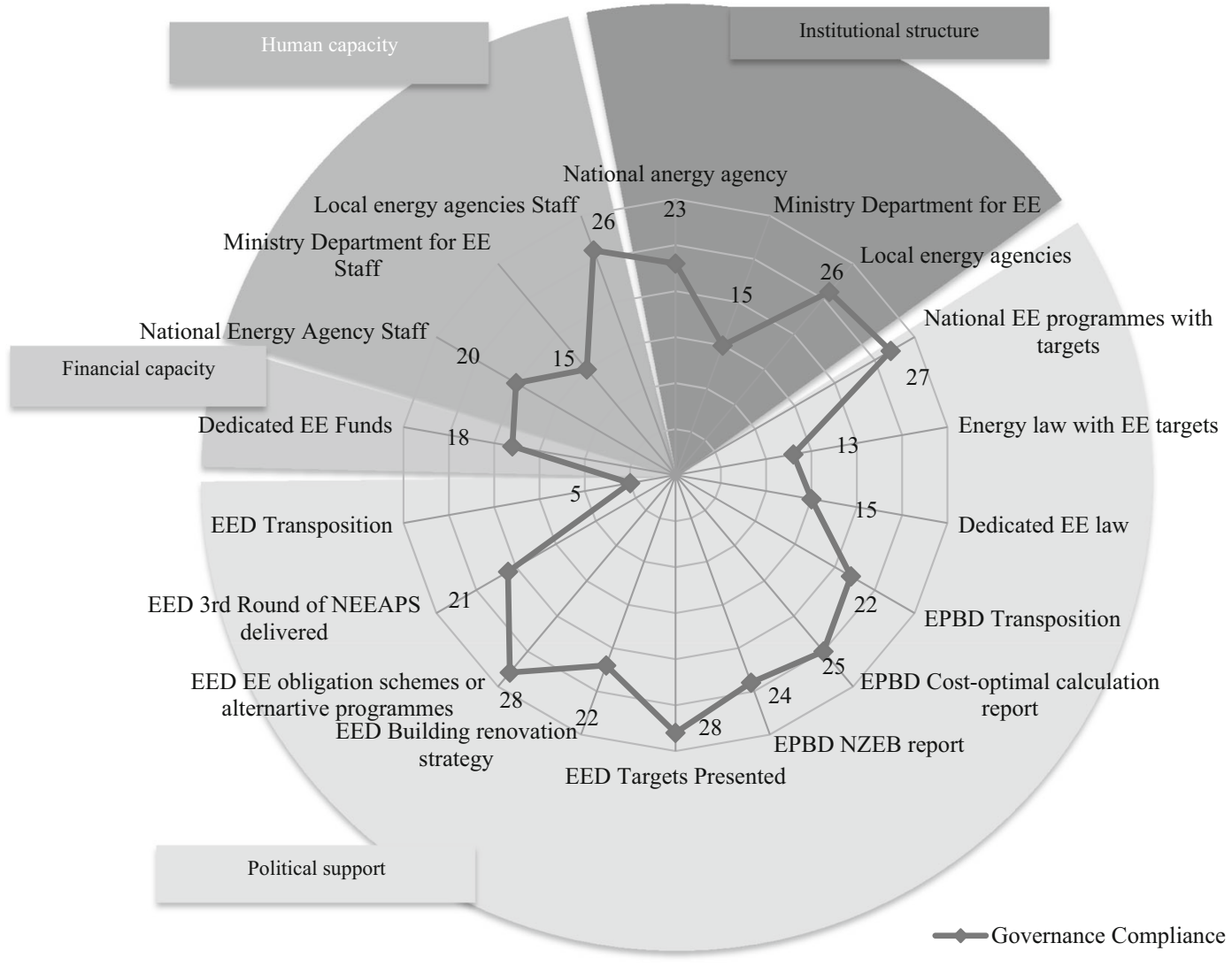

Fig. 7 EU governance analysis

over time, as well as their contribution to achieving set targets, can be essential in understanding the possibilities for meeting the EE target of $20 \%$ by 2020 and the more ambitious $30 \%$ target for 2030. From the obtained EU-wide scenario, we see that there is room for improving existing governance capacities, which can be observed as an opportunity for delivering planned EE improvement targets.

Member State governance capacity cluster results

The development of governance capacity clusters had as main goal to map the best performing Member States, according to the selected governance analysis criteria, whilst providing also information on Member States where stronger efforts have to be implemented to ensure a good level of EE governance.
For this purpose, three different clusters were defined to aggregate Member States. ${ }^{3}$ From the point assignment method presented (see Table 5) and considering the governance criteria used for analysis, any Member State can score a maximum of 18 points (i.e. when complying with all the indicators) and a minimum of -18 points (i.e. when failing to comply with all the indicators). The intervals used to group the Member States and a brief description of the categories are presented in the following table (Table 6).

\footnotetext{
${ }^{3}$ The results presented include acronyms for each Member State as follows: Austria: AT, Belgium: BE, Bulgaria: BG, Croatia: HR, Cyprus: CY, Czech Republic: CZ, Denmark: DK, Estonia: EE, Finland: FI, France: FR, Germany: DE, Greece: EL, Hungary: HU, Ireland: IE, Italy: IT, Latvia: LV, Lithuania: LT, Luxembourg: LU, Malta: MT, Netherlands: NL, Poland: PL, Portugal: PT, Romania: RO. Slovakia: SK, Slovenia: SI, Spain: ES, Sweden: SE, United Kingdom: UK
} 
Table 6 Defined clusters

\begin{tabular}{|c|c|c|}
\hline Clusters & $\begin{array}{l}\text { Performance } \\
\text { point interval }\end{array}$ & Brief description \\
\hline First League & $>14$ points & $\begin{array}{l}\text { Top-performing Member } \\
\text { States, contributing to the } \\
\text { EE development and } \\
\text { serving as potential } \\
\text { sources for best-case } \\
\text { practises }\end{array}$ \\
\hline Second League & $\leq 14$ and $>5$ points & $\begin{array}{l}\text { Member States with a } \\
\text { medium-low governance } \\
\text { performance }\end{array}$ \\
\hline Third League & $\leq 5$ points & $\begin{array}{l}\text { Member States with a low } \\
\text { performance, which can } \\
\text { benefit from best-case } \\
\text { practises observed in First } \\
\text { League Member States, as } \\
\text { well as from stronger } \\
\text { contributions from the EC } \\
\text { to align strategies to } \\
\text { overcome existing gaps in } \\
\text { EE governance }\end{array}$ \\
\hline
\end{tabular}

The point assignment process supports the distribution of Member States through the defined clusters, which is presented in the following table (Table 7).

Considering the categories defined in Table 6, for the evaluated criteria based on the available information, Cyprus, Denmark, and Italy are at the forefront of governance capacities for the analysed dimensions, being part of the First League cluster, whilst Greece, Romania, and Slovenia have registered a lower performance being in the Third League cluster. The remainder of the Member States present an intermediate governance capacity, being part of the Second League cluster.

The results obtained demonstrate the existing gap in the EU in terms of EE governance capacities. This analysis validates the need to further develop the governance framework, to align the Member State governance levels to a highly collaborative standard based on the timely implementation of policies and national plans for EE, amongst the other instruments on the scope of the energy and climate agenda.

\section{Conclusion}

In line with the need for a more robust EE governance framework, it is important to understand the current level of governance capacities in the EU, which was the focus of this study. For this purpose, a first analysis was conducted applying the governance analysis model from Jollands and Ellis (2009). From the dimensions analysed, the political support is the main source of concerns. Member States are failing to comply with the transposition of EU Directives, designed to drive impetus towards higher levels of EE. The financial resource dimension has also potential for improvement considering that from this research, only 18 Member States have been identified as having dedicated EE funding instruments. Regarding the institutional structures and human capacity, the analysis performed was based on public entities and agencies; these indicators present the existence of a good network of national and local energy agencies, in parallel with fewer ministry departments for EE.

\section{Policy implications}

The results obtained provide policy-relevant information to structure strategic plans that tackle the identified governance capacity gaps. In addition, these present an overview of the existing governance capacities allowing policymakers to understand existing governance strengths and weaknesses.

The complementary Member State clusters on governance performance (see Table 7) can be valuable when devising national, regional, and EU-wide strategies, funding programmes and $\mathrm{EE}$ targets, to ensure that these are realistic, considering the ability of Member States to deliver.

Policymakers working on the governance framework for the post-2020 goals should focus on the definition of clear and comparable indicators. These can be developed in collaboration with Member States. It is also important to ensure that the data to be collected allows

Table 7 Member State governance performance clusters

\begin{tabular}{llr}
\hline First League & Second League & Third League \\
\hline CY, DK, and IT & AT, BE, BG, CZ, DE, EE, ES, FI, FR, HR, HU, IE, LT, LU, LV, MT, NL, PL, PT, SE, SK, and UK & EL, RO, and SI \\
\hline
\end{tabular}

The Member States included in each cluster are organised alphabetically 
for the assessment of the evolution of governance capacities across Member States. The EC on the scope of the Energy Union agenda should coordinate the process of developing a set of key governance indicators, to be reported by Member States on a regular basis and made publicly available.

Obtaining a better understanding of the current level of EE governance through robust indicators can contribute to a timelier adaptation of the institutional, human, financial, and political dimensions. This gains further relevance considering the ongoing momentum associated with the Clean Energy for All Europeans policy package, which proposed overhauling changes to the EED, EPBD, and reinforced the impetus of the Ecodesign and Labelling Directives (European Commission 2016b).

\section{Study limitations}

The analysis was based on publicly available information on the governance indicators. It is important to note that Member State performance may be depicted as better or worse than it is in reality, given the impossibility to access the necessary data to point a particular indicator. Despite the effort of the authors that based the data collection process in reliable databases, some information was not available. This barrier encountered in the data collection analysis serves also as a suggestion for Member States and the EC to communicate this data, and other of similar nature, in a more organised manner, reducing the information access barrier.

\section{Future developments}

Future work can include analyses of the interrelations, between the various governance dimensions (e.g. the impact of the institutional structure on the timely transposition of directives). The analysis of these interlinks can contribute further to prioritising and informing decision makers on where to act, to deliver greater levels of EE. Moreover, additional indicators could be collected in terms of financial capacity, possibly looking for Research and Development-related funding at each Member State developed through national funding programmes. For the human capacity dimension, the analysis should evolve to include governance indicators related to available skills at each Member State for specific EE activities (e.g. sustainable building construction skills, building renovation skills, energy efficiency technology installation skills, clean technology development skills, energy audit skills, to name a few). The institutional structure dimension herein presented was based on support structures; the governance analysis can be complemented by including indicators from the private sector (e.g. indicators on the number of companies working in the field of EE). Additionally, researchers and policymakers may further develop this research by analysing the connection between energy efficiency governance capacities and actual energy efficiency performance. This can bring important insights to validate the role of good governance for EE plans, as well as for climate and energy policies facilitating the energy transition.

Acknowledgements The authors acknowledge the Portuguese National Foundation for Science and Technology (FCT) for supporting this work through the Doctoral Grant PD/BD/ 105841/2014, awarded on the framework of the MIT Portugal Program funded through the POPH/FSE. Additionally, this work has been partially supported by FCT under project grants UID/ MULTI/00308/2013 and SAICTPAC/0004/2015-POCI-01-0145FEDER-016434, as well as by the Energy for Sustainability Initiative of the University of Coimbra.

\section{Compliance with ethical standards}

Conflict of interest The authors declare that they have no conflict of interest.

\section{References}

Bazilian, M., Nakhooda, S., \& Graaf, T. (2014). Energy governance and poverty. Energy Research and Social Science, 1(2014), 217-225.

Bertoldi, P., \& Rezessy, S. (2009). Energy saving obligations and tradable white certificates. European Commission Joint Research Centre. Ispra. https://ec.europa. eu/energy/sites/ener/files/documents/2009_12_jrc_white_ certificates.pdf. Accessed 08 Dec 2016.

Bonn, M., Heitmann, N., Reichert, G., Voßwinkel, J. (2015). EU Climate and Energy Policy 2030 comments on an evolving framework. Freiburg. http://www.cep.eu/Studien/cepInput_ Klima_und_Energie/cepInput_Climate_and_Energy_ Policy_2020-2030.pdf. Accessed 0 1 Dec 2015.

Davies, J. (2006). Local governance and the dialectics of hierarchy, market and network. Policy Studies, 26(3-4), 311-335.

Delina, L. (2012). Coherence in energy efficiency governance. Energy for Sustainable Development, 16(4), 493-499.

multiEE. (2015). multEE Project Briefing in a nutshell. http://multee.eu/system/files/multEE_Project Briefing_2016_0.pdf. Accessed 22 Feb 2017. 
Eurelectric (2015). Energy Union and 2030 energy \& climate governance. Brussels. http://www.eurelectric. org/media/172021/governance_paper_2015_final_ version_21-04-2015-2015-030-0210-01-e.pdf. Accessed $3 \overline{0}$ Nov 2015.

European Commission (2010). Europe 2020. A strategy for smart, sustainable and inclusive growth. - COM(2010) 2020 final. Brussels.

European Commission (2011a). Background on energy in Europe. Brussels.

European Commission (2011b). Energy 2020 - a strategy for competitive, sustainable and secure energy. Brussels.

European Commission (2011c). Energy roadmap 2050 COM(2011) $885 / 2$. Brussels.

European Commission (2011d). The commission's new Energy Efficiency Directive-MEMO/11/440-22 June 2011. Brussels.

European Commission (2013a). "European Commission Energy Star Programme." http://www.eu-energystar.org/en/en_016. shtml. Accessed 12 Dec 2013.

European Commission (2013b). Green paper - a 2030 framework for climate and energy policies- $\operatorname{COM}(2013) 169$ final. Brussels.

European Commission (2013c). "GreenBuilding ProgrammeEuropean Commission." http://iet.jrc.ec.europa. eu/energyefficiency/greenbuilding-programme/aboutgreenbuilding-programme. Accessed 12 Dec 2013.

European Commission (2013d). "GreenLight ProgrammeEuropean Commission." http://iet.jrc.ec.europa. eu/energyefficiency/greenlight. Accessed 12 Dec 2013.

European Commission (2013e). Questions and answers: green paper framework for climate and energy policies-MEMO. Brussels.

European Commission (2014a). 2030 climate and energy goals for a competitive, secure and low-carbon EU economy, IP/14/54. Brussels.

European Commission (2014b). A policy framework for climate and energy in the period from 2020 to $2030, \operatorname{COM}(2014) 15$ final. Brussels.

European Commission (2014c). Climate and energy priorities for Europe: the way forward. Brussels.

European Commission (2014d). Energy efficiency and its contribution to energy security and the 2030 framework for climate and energy policy, Annexes 1 of 3, $\operatorname{COM(2014)} 520$ final. Brussels.

European Commission. (2014e). Energy efficiency and its contribution to energy security and the 2030 framework for climate and energy policy, $\operatorname{COM(2014)} 520$ final. Brussels.

European Commission. (2015a). Assessment of the progress made by Member States towards the national energy efficiency targets for 2020 and towards the implementation of the Energy Efficiency Directive 2012/27/EU as required by Article 24 (3) of Energy Efficiency Directive 2012/27/EU. Brussels. https://ec.europa.eu/energy/sites/ener/files/ documents/1_EEprogress_report.pdf. Accessed 21 Nov 2016.

European Commission (2015b). "Energy Efficiency Directive target reporting." DG Energy Portal. http://ec.europa. eu/energy/efficiency/eed/eed_en.htm. Accessed 16 Jan 2015.

European Commission. (2015c). Energy Union package. Brussels. http://eur-lex.europa.eu/resource.html?uri=cellar:1bd46c90-
bdd4-11e4-bbe1-01aa75ed71a1.0001.03/DOC_1\&format= PDF. Accessed 21 Nov 2016.

European Commission. (2015d). State of the Energy Union 2015. Brussels. https://ec.europa.eu/transparency/regdoc/rep/1 /2015/EN/1-2015-572-EN-F1-1.PDF. Accessed 22 Feb 2017.

European Commission. (2016a). Clean energy for all-the new energy efficiency measures. Brussels. https://ec.europa. eu/energy/sites/ener/files/documents/technical_memo_ energyefficiency.pdf. Accessed 22 Feb 2017.

European Commission. (2016b). Clean energy for all Europeans. Brussels. http://ec.europa.eu/energy/sites/ ener/files/documents/com_860 final.pdf. Accessed 22 Feb 2017.

European Commission. (2016c). Ecodesign Working Plan 20162019. Brussels. http://eur-lex.europa.eu/legalcontent/EN/TXT/PDF/?uri=CELEX:52016DC0773\&from= EN. Accessed 22 Feb 2017.

European Commission. (2016d). Proposal for a Directive of the European Parliament and of the Council amending Directive 2010/31/EU on the energy performance of buildings. Brussels. http://ec.europa.eu/energy/sites/ ener/files/documents/1_en_act_part1_v10.pdf. Accessed 22 Feb 2017.

European Commission. (2016e). Proposal for a directive of the European Parliament and of the Council amending Directive 2012/27/EU on Energy Efficiency. Brussels. http://eur-lex. europa.eu/resource.html?uri=cellar:efad95f3-b7f5-11e6-9e3 c-01aa75ed71a1.0009.02/DOC_1\&format=PDF. Accessed 22 Feb 2017

European Commission. (2017a). 2016 assessment of the progress made by Member States in 2014 towards the national energy efficiency targets for 2020 and towards the implementation of the Energy Efficiency Directive 2012/27/EU as required by Article 24 (3) of the Energy Efficiency Directive. Brussels. https://ec.europa.eu/commission/file/2470/download en?token=OFLxIK45. Accessed 22 Feb 2017.

European Commission. (2017b). Second report on the state of the Energy Union. Brussels. https://ec.europa. eu/transparency/regdoc/rep/1/2017/EN/COM-2017-53-F1EN-MAIN-PART-1.PDF. Accessed 22 Feb 2017.

European Council. (2014). Conclusions adopted by the European Council meeting. EUCO 169/14 on the 2030 Climate and Energy Policy Framework. Brussels. http://data.consilium. europa.eu/doc/document/ST-169-2014-INIT/en/pdf. Accessed 21 Nov 2016.

European Union. (2004) Directive 2004/8/EC of the European Parliament and of the Council of 11 February 2004 on the promotion of cogeneration based on a useful heat demand in the internal energy market and amending Directive 92/42/ EEC, Official Journal Of The European Union 50-60 (2004).

European Union. (2006). Directive 2006/32/EC of the European Parliament and the Council of the European Union of 5 April 2006. European Union: Official Journal of the European Union.

European Union. (2009) Directive 2009/125/EC of the European Parliament and of the Council of 21 October 2009 establishing a framework for the setting of ecodesign requirements for energy-related products (recast), Official Journal of the European Union. 
European Union. (2010a) Directive 2010/30/EU of the European Parliament and of the Council; on the indication by labelling and standard product information of the consumption of energy and other resources by energy-related products (recast), Official Journal of the European Union.

European Union (2010b). Directive 2010/31/EU of the European Parliament and of the Council of 19 May 2010 on the energy performance of buildings (recast). Official Journal of the European Union.

European Union (2012a). Delivering on the Europe 2020 strategy - handbook for local and regional authorities. Brussels.

European Union (2012b). Directive 2012/27/EU of the European Parliament and of the Council of 25 October 2012 on Energy Efficiency, Amending Directives 2009/125/EC and 2010/30/ EU and Repealing Directives 2004/8/EC and 2006/32/EC. Vol. 4. European Union: Official Journal of the European Union.

Faber, J., Schroten, A., Bies, M., Sevenster, M., Markowska, A., Smit, M., Rohde, C. et al. (2012). Behavioural climate change mitigation options and their appropriate inclusion in quantitative longer term policy scenarios. Delft, April 2012.

Florini, A., \& Sovacool, B. (2009). Who governs energy? The challenges facing global energy governance. Energy Policy, 37(12), 5239-5248.

Gisselquist, R. (2014). Developing and evaluating governance indexes: 10 questions. Policy Studies, 35(5), 513-531.

Golubchikov, O., \& Deda, P. (2012). Governance, technology, and equity: an integrated policy framework for energy efficient housing. Energy Policy, 41, 733-741.

Gupta, J., \& Ivanova, A. (2009). Global energy efficiency governance in the context of climate politics. Energy Efficiency, 2(4), 339-352.

Harmsen, R., Eichhammer, W., \& Wesselink, B. (2014). An exploration of possible design options for a binding energy savings target in Europe. Energy Efficiency, 7(1), 97-113.

IEA. (2010). Energy efficiency governance - handbook-second edition. Paris: International Energy Agency http://www.iea. org/publications/freepublications/publication/name,3931,en. html. Accessed 01 Feb 2016.

IEA, (2014). Capturing the multiple benefits of energy efficiency-executive summary. Paris.

Jollands, N., Ellis, M. (2009). Energy efficiency governance-an emerging priority-ECEEE summer studies 2009. Edited by Nigel Jollands and Mark Ellis. European Council for an Energy Efficient Economy.

Jollands, N., Gasc, E., \& Pasquier, S. (2009). Innovations in multilevel governance for energy efficiency. Paris: International Energy Agency.

Karlsson-Vinkhuyzen, S., Jollands, N., \& Staudt, L. (2012). Global governance for sustainable energy: the contribution of a global public goods approach. Ecological Economics, $83,11-18$
Kempe, R. (2011). Investing in capacity development: towards an implementation framework. Policy Studies, 32(1), 59-72.

Meyer-Ohlendorf, N., Duwe, M., Roberts, E., Umpfenback, K. (2015). An effective governance system for $2030 \mathrm{EU}$ climate and energy policy: design and requirements discussion paper. Berlin. http:/www.ecologic.eu/sites/files/publication/2015 /meyer-ohlendorf-15-effective-governance-syystem-2030. pdf. Accessed 29 Nov 2015.

Nesbit, M. (2014). Getting delivery right: the EU 2030 climate and energy targets and the challenge of governance. London. http://www.ieep.eu/assets/1659/IEEP_EU2030 governance_paper.pdf. Accessed 01 Dec 2015.

Ringel, M., Schlomann, B., Krail, M., \& Rohde, C. (2016). Towards a green economy in Germany? The role of energy efficiency policies. Applied Energy, 179, 1293-1303.

Sartor, O., Spencer, T., Bart, I., Cochran, I., Colombier, M., Neuhoff, K., Szpor, A., Tuerk, A., and Wyns, T. (2014). What is needed in the EU's 2030 climate and energy framework. www.climatestrategies.org. Accessed 01 Dec 2015.

Schlomann, B., Rohde, C., \& Plotz, P. (2015). Dimensions of energy efficiency in a political context. Energy Efficiency, 8(1), 97-115.

Schüle, R., Aydin, V., Fischer, J., Thomas, M., Thomas, S., Becker, D., Bader, N. (2013). Improving and implementing national energy efficiency strategies in the EU framework. www.energy-efficiency-watch.org. Accessed 28 March 2015.

Steuwer, D. (2012). Energy efficiency governance-the case of white certificate instruments for energy efficiency in Europe. Berlin: Springer.

Tasdoven, H., Fiedler, B., \& Garayev, V. (2012). Improving electricity efficiency in Turkey by addressing illegal electricity consumption: a governance approach. Energy Policy, 43, 226-234.

Turner, S. (2015). Embedding principles of good governance into the 2030 climate and energy framework. Brussels. http://www.foeeurope.org/sites/default/files/renewable energy/2015/turner_2015-six_principles_of_good_ governance.pdf. Accessed 03 Dec 2015.

Turner, S., Genard, Q., Roberts, J., Luebbeke, I. (2015). Four key messages for the governance of European climate and energy policies after 2020. http://www.e3g.org/docs/E3G_Four_ Key_Messages_for_the_governance_of_EU_climate_and energy_policies_after_2020_V2.pdf. Accessed 03 Dec 2015.

European Union (2013). Report on the energy roadmap 2050, a future with Energy (2012/2103(INI)) Committee on Industry, Research and Energy. Brussels.

World Energy Council (2015). Energy efficiency policies and measures database. Paris. https://www.worldenergy. org/data/energy-efficiency-policies-and-measures/. Accessed 05 Feb 2016. 